\title{
The effect of different shading net on the Quantum Efficiency of PS II in chilli pepper cultivar 'Star Flame'
}

\author{
Stella Agyemang Duah - Zsuzsa Nagy - Lajos Helyes \\ Department of Horticulture, Szent Istvan University, 2100 Godollo Pater Karoly utca 1 Hungary \\ ladystagy1@gmail.com
}

\begin{abstract}
SUMMARY
The study was undertaken to identify the effect of different shading net on the quantum efficiency of PS II on 'Star Flame' chilli pepper (Capsicum annuum) over a period of time cultivated under plastic house environment. 'Star Flame' pepper was grown under red shading net and samples without shading were used as control. Analysis of photosynthetic activity revealed a significant difference ( $p<0.05$ ) between $F v / F m$ values in control and red shading at the end of July $(p=0.031)$ after the first harvest. Chlorophyll fluorescence parameter Fv/Fm reflects the maximum quantum efficiency of photosystem II (PS II) used in the detection of early stress in plants.
\end{abstract}

Keywords: shading nets, chlorophyll fluorescence, harvesting time, greenhouse

\section{INTRODUCTION}

Pepper (Capsicum sp.) is a member of the Solanaceae family and commonly divided into two groups known as pungent and non-pungent. Hot pepper is one of the vegetable crops commonly grown and consumed in Countries like China, Africa, Korea and many other countries for its nutritional composition such as antioxidant compounds and natural colors, like carotenoids and vitamin C (Howard et al., 2000). Hot peppers contain capsaicinoids that gives the fruit its pungency as well as their pharmacological attributes (Thiele et al., 2008). The use of shading net is mostly done to protect cultivated crops from excessive solar radiation, improve thermal climate (Kittas et al., 2009), providing shelter for crops against wind and hail and also prevent birds and insects from transmitting viral diseases (Teitel et al., 2008). Assertion made by Kittas et al. (2009) indicates that net shading of crops can result in changes on both local microclimate and crop activity. These changes may modify $\mathrm{CO}_{2}$ assimilation and consequently improve crop growth and development. The use of shading nets modifies light environment, thus affecting light regulated activities in plants (Fallik et al., 2010). Combining different shading nets techniques resulted in better crop yields and lower susceptibility to decay during post-harvest storage compared to traditional shading methods (Stamps, 2009; Shahak, 2014). Yellow coloured mesh shades increased open field pepper yield and quality compared to traditional black nets (Fallik et al., 2009), while both yellow and pearl coloured nets reduced the occurrence of Alternaria and improved post-harvest qualities of the product (Goren et al., 2011).

Ilic et al. (2011) observed that red and pearl shade nets significantly increased the total yield $(43.5 \%$ and $49.5 \%$ ) which was as a result of both higher productivity for number of fruits produced per plant and larger fruits. Pepper plants grown under black shading nets with $40 \%$ shade had higher yield (10.5\%) than plants grown without shading nets. Sharma et al. (2004) found out that cultivating of California Wonder species under greenhouse produced a greater number of fruits (15.03), fruit weight $\left(723.28 \mathrm{~g} \mathrm{plant}^{-1}\right)$ and more yield $\left(5.35 \mathrm{~kg} \mathrm{~m}^{-2}\right)$. It also recorded maximum plant height $(56.00 \mathrm{~cm})$, number of branches (5.86) and number of leaves (80.76) when compared to open field conditions.

Abiotic stress can have significant effects on photosynthetic activities of pepper plants and therefore the use of chlorophyll fluorescence measurements can give an indication on how healthy a plant looks (Nagy et al., 2017). When plants are not under any kind of stress, the optimal photochemical quantum efficiency of PS II, meaning the Fv/Fm measurement using a chlorophyll fluorescence meter, is usually expected to be 0.72-0.85 (Bolhar-Nordenkampf et al., 1989). In agreement to this assertion, a decrease in fluorescence was observed by Guang-cheng et al. (2011) in hot pepper during water stress. Chlorophyll fluorescence imaging (Chl-FI) is an important tool that is used to study the spatial and temporal heterogeneity of leaf photosynthesis under biotic stress and their responses to the stress (Nedbal and Whitmarsh, 2004) which could be related to physiological alterations in bacteria affected plants (Bonfig et al., 2006). The current study aimed to investigate the effect of red shading net on the quantum efficiency of PS II in 'Star Flame' chilli pepper grown under plastic house environment.

\section{MATERIALS AND METHODS}

\section{Plant material}

The study was conducted at the experimental field of the Horticulture Institute, Szent István University, Gödöllö, Hungary (lat. $47^{\circ} 61^{\prime} \mathrm{N}$, long. $19^{\circ} 32^{\prime}$ E) with soils mainly sandy loam classified as Cambisol with 1.8-2\% humus content and an approximate $\mathrm{pH}$ of 7. Capsicum annum L. hybrid, 'Star Flame' seeds were purchased from Seminis ${ }^{\circledR}$ (Kecskemét, Hungary) and were nursed on February 29, 2014 in propagation trays with holes. Seedlings were then transplanted on April 27,2014 into a $30 \mathrm{~m}$ (length) $\times 4 \mathrm{~m}$ (width) $\times 2.5 \mathrm{~m}$ (height) greenhouse in twin rows with a spacing of 0.4 $\mathrm{m}$ between plants and rows, and $0.8 \mathrm{~m}$ between twin rows, therefore creating a planting density of 4.167 
plants $\mathrm{m}^{-2}$ out into individual pots in a greenhouse that had an average daytime temperature of $20^{\circ} \mathrm{C}$.

\section{Net characteristics}

Different sections of the plastic house were covered with red (ChromatiNet, Ginegar, Israel) shading nets to alter the light environment. A non-shaded net (control) was also used in the same greenhouse. Each net was specified by the manufacturer to have a $40 \%$ shading ratio. Nets were placed perpendicular to the twin rows over a space $8 \mathrm{~m}$ in width, thus creating a block under which four biological replicates were randomly appointed. Ten plants were selected from each replicate, which were used to measure chlorophyll fluorescence (quantum efficiency of PS II).

\section{Measurement of Light Parameters}

A portable PAM 2500 fluorometer (Walz-Mess und Regeltechnik, Germany) was used to measure chlorophyll fluorescence in experimental plants. One measurement was made per week during a four-week period on a sunny day at noon before each harvest time, whereby four fully developed top leaves of a single plant from each replicate were affixed with leaf clips for a $35 \mathrm{~min}$ dark adaption before fluorescence measurement. Maximum quantum efficiency of PSII was quantified using the Fv/Fm ratio determined by the fast kinetics method in the PamWin 3.0 software (Van Goethem et al., 2013).

\section{Statistical Analyses}

Results were expressed as mean of four replicates \pm standard errors. Mean separation of light parameters and day of measurement was investigated using independent sample test with $\mathrm{p}<0.05$. Statistical analyses were performed using IBM SPSS 22 software (IBM, USA).

\section{RESULTS AND DISCUSSION}

From the investigation in Figure 1, the use of red shading net had no significant difference in the Fv/Fm values measured between June 18 and July 28. It was observed after the first harvest a significant difference $(\mathrm{p}<0.05)$ in the measurement of Fv/Fm values $\mathrm{p}=$ 0.031 that indicated stress in plants which corroborates with the assertion made by Guang-cheng et al. (2011). A decrease in fluorescence measurement indicates a decrease in chlorophyll which could be as a result of poor irrigation or possibly high temperature stress causing Fv/Fm values to decrease (Hanying et al., 2001). Photosynthetic activities are influenced by a number of factors such as leaves position, stage of development, light intensity and composition (Borisev et al., 2012). Chlorophyll fluorescence accounts for only $1-2 \%$ of the total absorbed light which practically quantifies abiotic factors. For this quantification, the $\mathrm{Fv} / \mathrm{Fm}$ value is used, which is the quotient of the variable fluorescence and the maximum fluorescence, with this value being characterized by the maximum quantum efficiency of the PSII photosynthetic system. Measurement of $\mathrm{Fv} / \mathrm{Fm}$ values of red shading net between August 04 and September 28 indicated no significant differences $(\mathrm{p}<0.05)$. Zhu et al. (2012) investigated that $\mathrm{Fv} / \mathrm{Fm}$ values of peppers grown on shadowing (unshaded, 30\%, 70\%) and on the surface water capacity $(40-55 \%, 55-70 \%, 70-85 \%, 85-100 \%)$ was found that $70 \%$ shielded and $55-70 \%$ moisturized plants are the highest.

Figure 1: Influence of different shading net on the quantum efficiency of PS II in 'Star Flame' chilli pepper grown under greenhouse environment (Fv/Fm values)

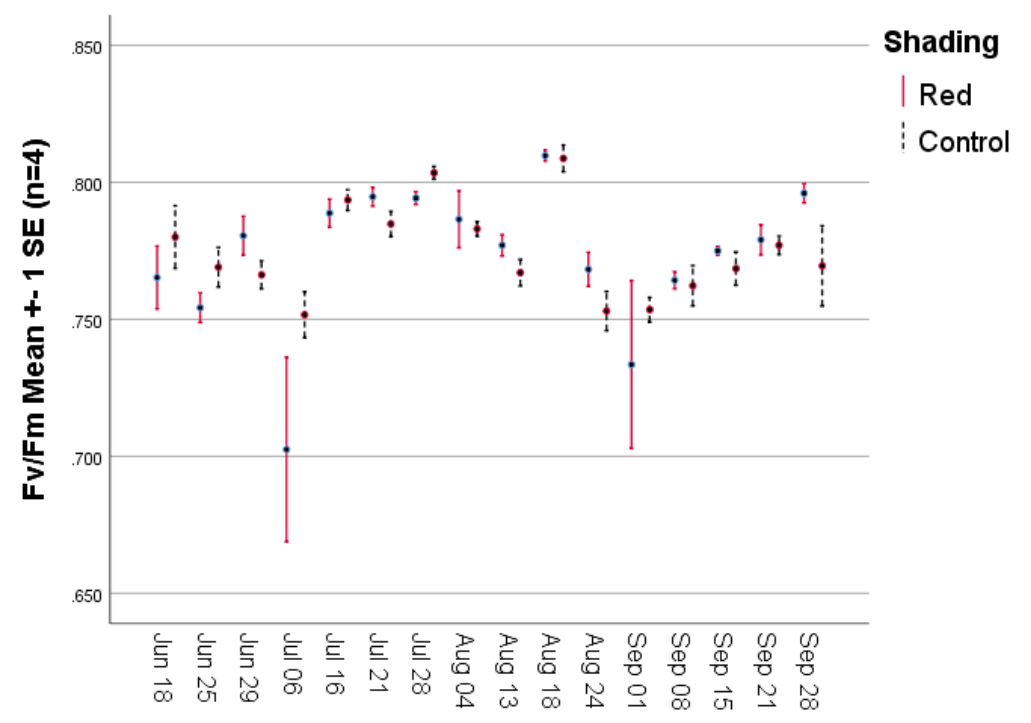

Day of measurement 


\section{CONCLUSION}

The use of different shading nets provides a new, multi-benefit tool for crop protection. Changing the light intensity in a greenhouse environment has a great impact on the microclimate and energy consumption are influenced, costs and benefits are affected. Research on different light exposure in the agricultural system is necessary for a sustainable and marketoriented greenhouse production of crops in the future even though red shading nets used in this experiment did not extensively affect fruit quality.

\section{ACKNOWLEDGEMENT}

This study was funded in part by Research Centre of Excellence- 9878-3/2016/FEKUT. The study was supported by Department of Horticulture, Szent Istvan University, Godollo and Tempus Public Foundation.

\section{REFERENCES}

Bolhar-Nordenkampf, H. R.-Long, S. P.-Baker, N. R.-Öquist, G.Schreiber, U.-Lechner, E. G. (1989): Chlorophyll fluorescence as a probe of the photosynthetic competence of leaves in the field: a review of current instrumentation. Funct Ecol 3:497-514. doi.org/10.2307/2389624

Bonfig, K. B.-Schreiber, U.-Gabler, A.--Roitsch, T.-Berger, S (2006): Infection with virulent and avirulent P. syringaestrains differentially effects photosynthesis and sink metabolism in Arabidopsis leaves. Planta 225: 1-12, 2006.

Fallik, E.-Alkalai-Tuvia, S.-Parselan, Y.-Aharon, Z.-Elmann, A.Offir, Y.-Matan, E.-Yehezkel, H.-Ratner, K.-Zur, N.-Shahak, Y. (2009): Can colored shade nets maintain sweet pepper quality during storage and marketing? Acta Horticulturae 830:37-44.

Fallik, E.-Goren, A.-Alakali-Tuvia, S.-Perzelan, Y.-Aharon, Z.Sharak Y. (2010): The effect of colored shade nets on sweet bell pepper quality after prolonged storage and shelf life. Book of abstracts of 28th International Horticultural Congress. Lisboa, Portugal, Volume II, p. 198.

Goren, A.-Alkalai-Tuvia, S.-Perzelan, Y.-Fallik, E.-Aharon, Z (2011): Photoselective shade nets reduce postharvest decay development in pepper fruits. Advances in Horticultural Science 25:26-31.

Guang-cheng, S.-Rui-qi, G.-Na L.-Shuang-en, Y.-Weng-gang, X. (2011): Photosynthetic, chlorophyll fluorescence and growth changes in hot pepper under deficit irrigation and partial root zone drying. Afr J Agric Res 6:4671-4679. doi:10.5897/AJAR11.812

Hanying, W.-Shenyan, S.-Zhujun, Z.-Xinting, Y. (2001): Effects of high temperature stress on photosynthesis and chlorophyll fluorescence in sweet pepper (Capsicum fructescens L.). Acta Hortic Sinica 28:517-521

Howard, L. R.-Talcott, S. T.-Brenes, C. H. (2000): Changes in phytochemical and antioxidant activity of selected pepper cultivars (Capsicum species) as influenced by maturity. J. Agric. Food Chem., 48: 1713-1720

Kittas, C.-Rigakis, N.-Katsoulas, N.-Bartzanas, T. (2009): Influence of shading screens on microclimate, growth and productivity of tomato. Acta Hort. 807: 97-102.
Ilic, Z.-Milenkovic, L.-Durovka, M.-Kapoulas, N. (2011): The effect of color shade nets on the greenhouse climate and pepper yield. 46th Croatian and sixth International Symposium on Agriculture. Opatija, Croatia, pp. 529-533.

Nagy, Z.-Daood, H. G.-Ambroxy, Z.-Helyes, L. (2017): Impact of Shading Net Color on Phytochemical Contents in Two Chili Pepper Hybrids Cultivated Under Greenhouse Conditions. Horticultural Science and Technology 35(3):000-000, 2017

Nedbal, L.-Whitmarsh, J. (2004): Chlorophyll fluorescence imaging of leaves and fruits. - In: Papageorgiou, C.G., Govindjee (ed.): Chlorophyll A Fluorescence: A Signature of Photosynthesis. Pp. 389-407. Springer, Dordrecht.

Shahak, Y. (2014): Photoselective netting: An overview of the concept, $\mathrm{R} \& \mathrm{D}$ and practical implementation in agriculture. Acta Horticulturae 1015:155-162.

Sharma, H. G.-Agarwal, N.-Dubey, P.-Dixit, A. (2004): Comparative performance of capsicum under controlled environment and open field condition. Ann. Agric. Res., 25 (4):638-640.

Stamps, R. H. (2009): Use of colored shade nettings in horticulture. HortScience 44:239-241.

Teitel, M.-Liron, O.-Haim, Y.-Seginer, I. (2008): Flow through inclined and concertina-shape screens. Acta Hort. 801: 99-106.

Thiele, R.-Mueller-Seitz, E.-Petz, M. (2008): Chili Pepper Fruits: Presumed Precursors of Fatty Acids Characteristic for Capsaicinoids. Journal of Agricultural and Food Chemistry 2008 56 (11), 4219-4224 DOI: 10.1021/jf073420h

Van Goethem, D.-Smedt De, S.-Valcke, R.-Potters, G.-Samson, R. (2013): Seasonal, diurnal and vertical variation of chlorophyll fluorescence on Phyllostachys humilis in Ireland. PLoS ONE 8:72145. doi.org/10.1371/journal.pone.0072145

Zhu, J. J.-Peng, Q.-Liang, Y. L.-Wu, X.-Hao, W. L. (2012): Leaf gas exchange, chlorophyll fluorescence, and fruit yield in hot pepper (Capsicum аппиит L.) grown under different shade and soil moisture during the fruit growth stage. Journal of Integrative Agriculture. 11: 6. 927-937. DOI: http://dx.doi.org/10.1016/S2095- 3119(12)60083-5 
